\title{
Peningkatan Perilaku Inovatif Perajin Tenun Melalui Perilaku Berbagi Pengetahuan dan Efikasi Diri
}

\author{
Sulistiowati* \\ Fakultas Ekonomi dan Bisnis, Universitas Tanjungpura, Indonesia
}

\begin{abstract}
Innovation is needed for creative businesses, especially crafts. Innovative behavior is closely related to innovation. This study aims to analyze the influence of knowledge sharing on the innovative behavior of weaving crafters and how the effect of self-efficacy on the innovative behavior of weaving crafters. The study was conducted on 50 weaving craftsmen in Sambas Regency, Kalimantan Barat Province. The conclusion of descriptive statistical analysis is the innovative behavior of weaving crafters in the very high category, knowledge sharing behavior in high category, and self efficacy in the very high category. Hypothesis testing is done by multiple regression analysis, with SPSS 20.0 software. The results of this study concluded that there was no significant influence of knowledge sharing behavior on the innovative behavior of weaving crafters, and there was a significant effect of self-efficacy on the innovative behavior of weaving crafters.
\end{abstract}

Keywords: innovative behavior, knowledge sharing, self efficacy

\section{PENDAHULUAN}

Kain tenun Sambas merupakan salah satu bentuk produk andalan di Kabupaten Sambas, Proponsi Kalimantan Barat. Proses menenun dengan tangan (handmade) membuat kain tenun menjadi unik dan bernilai tinggi. Walaupun mempunyai nilai sejarah, budaya, dan ekonomis yang tinggi, ternyata tenun sambas mulai menurun eksistensinya. Hal tersebut dapat dilihat dari berkurangnya jumlah perajin tenun serta kurang terserapnya produk di pasar. Untuk mengatasi hal itu dapat dilakukan dengan meningkatkan variasi motif tenun dan diversifikasi produk. Variasi motif tenun dapat ditingkatkan dengan menciptakan motif yang berbeda dari yang sudah ada, sedangkan diversifikasi produk dapat dilakukan dengan membuat produk lain dari bahan kain tenun, misalnya tas, dompet, rok, hiasan dinding, dan lain sebagainya.

Kemampuan sumber daya manusia untuk selalu menghasilkan inovasi, merupakan faktor kunci bagi suatu bisnis untuk dapat bertahan dalam kondisi persaingan yang ketat. Untuk menambah variasi motif maupun diversifikasi produk diperlukan kemampuan berinovasi (innovation capability) dari perajin tenun. Innovation capability tiap individu

\footnotetext{
*Email : sulistiowati.soeharso@gmail.com

Received : 23-08-2018, Accepted : 04-09-2018, Published : 30-12-2018

P-ISSN : 2087-9954, E-ISSN : 2550-0066. DOI : http://dx.doi.org/10.26418/jebik.v7i3.27236
} 
berbeda, tidak semua individu memiliki bakat berinovasi. Innovation capability dapat berkembang karena adanya pengetahuan, baik tentang produk, teknik pembuatan maupun wawasan lain yang mendukung. Beberapa peneliti berpandangan bahwa salah satu upaya yang dipandang efektif dalam meningkatkan kemampuan inovasi sumber daya manusia adalah melalui pengembangan aktivitas berbagi pengetahuan, karena melalui aktivitas tersebut, knowledge dapat disebarkan, diimplementasikan dan dikembangkan. Di sisi lain, berbagi pengetahuan dapat merangsang individu untuk mampu berfikir lebih kritis dan kreatif, sehingga pada akhirnya dapat menghasilkan pengetahuan baru yang berguna bagi pengembangan usaha.

Perilaku berbagi pengetahuan memiliki peran penting bagi inovasi. Berbagi pengetahuan dianggap mampu menjadi pendorong peningkatan kemampuan inovasi (Lin, 2007; Rahab, Sulistyandari, \& Sudjono, 2011).Proses berbagi pengetahuan antar perajin tenun sangat penting untuk dilakukan. Berbagi pengetahuan yang dilakukan antar penenun akan mampu menciptakan kerja sama yang saling memberi dan menerima informasi dan pengetahuan, sehingga akan mendorong kemampuan penenun untuk menemukan ide-ide kreatif dalam melakukan inovasi.

Selain itu, keyakinan diri individu bahwa ia dapat melaksanakan tugasnya sebagaimana mestinya sangat penting untuk membangun kemampuan berinovasi. Konsep efikasi diri ini terkait dengan penilaian individu tentang kemampuan mereka untuk melakukan pekerjaan atau beradaptasi dengan kondisi tertentu. Individu dengan efikasi diri yang kuat memiliki kepercayaan diri yang tinggi tentang bagaimana dia dapat melakukan pekerjaan dengan baik dan mencapai kinerja yang tinggi. Riset terdahulu mengenai tercapainya hasil kerja yang diharapkan dipengaruhi oleh efikasi diri dilakukan oleh (Bandura, 2012). Efikasi diri dipercaya dapat memengaruhi pemilihan tugas, usaha, ketekunan, kegembiraan, dan prestasi (Bandura, 2012). Inovasi memerlukan usaha yang besar untuk periode yang panjang. Penelitian sebelumnya menunjukkan hasil yang positif antara efikasi diri dan perilaku inovasi pada guru di Taiwan (Hsiao, Tu, Chang, \& Chen, 2015).

Efikasi diri penenun sangat dibutuhkan untuk mendorong perilaku inovatif mereka. Pengetahuan yang diperoleh melalui proses berbagi pengetahuan diolah dengan keyakinan untuk dapat mengaplikasikan pengetahuan tersebut dalam berinovasi akan mendorong perilaku inovatif penenun dalam menghasilkan karya yang menarik konsumen.

\section{KAJIAN LITERATUR}

\section{1. Perilaku Inovatif}

Perilaku inovatif didefinisikan sebagai keseluruhan tindakan individu yang mengarah pada pemunculan, pengenalan, dan penerapan dari sesuatu yang baru dan menguntungkan pada seluruh tingkat organisasi. Sesuatu yang baru dan menguntungkan meliputi pengembangan ide produk baru atau teknologi-teknologi, perubahan dalam 
prosedur administratif yang bertujuan untuk meningkatkan relasi kerja atau penerapan dari ide-ide baru atau teknologi-teknologi untuk proses kerja yang secara signifikan meningkatkan efisiensi dan efektivitas mereka (Kleysen \& Street, 2001). Menurut (Jong \& Hartog, 2007). Perilaku inovatif dapat didefinisikan sebagai semua tindakan individu yang diarahkan pada generasi, pengenalan dan penerapan baru yang bermanfaat pada setiap tingkat organisasi. Sedangkan menurut Scott \& Bruce, (1994) perilaku inovatif yaitu sebagai intensi untuk memunculkan, meningkatkan dan menerapkan ide-ide baru dalam tugasnya, kelompok kerjanya atau organisasinya.

Menurut Jong \& Hartog, (2007) perilaku inovatif dalam melakukan proses inovasi dapat dibagi menjadi 4 tahap. Tahap pertama adalah melihat peluang. Melihat peluang bagi sumber daya manusia untuk mengidentifikasi berbagai peluang/kesempatan yang ada. Peluang dapat berawal dari ketidak kongruenan dan diskontinuitas yang terjadi karena adanya ketidaksesuaian dengan pola yang diharapkan misalnya timbulnya masalah pada pola kerja yang sudah berlangsung, adanya kebutuhan konsumen yang belum terpenuhi, atau adanya indikasi trends yang sedang berubah.

Tahap kedua adalah mengeluarkan ide. Dalam fase ini, karyawan mengeluarkan konsep baru dengan tujuan untuk perbaikan. Hal ini meliputi mengeluarkan ide sesuatu yang baru atau memperbaharui pelayanan, pertemuan dengan klien dan teknologi pendukung. Kunci dalam mengeluarkan ide adalah mengombinasikan dan mereorganisasikan informasi dan konsep yang telah ada sebelumnya untuk memecahkan masalah dan atau meningkatkan kinerja.

Tahap ketiga adalah memperjuangkan. Maksudnya disini untuk mengembangkan dan mengimplementasikan ide, karyawan harus memiliki perilaku yang mengacu pada hasil. Perilaku Inovasi Konvergen meliputi usaha menjadi juara dan bekerja keras. Seorang yang berperilaku juara mengeluarkan seluruh usahanya pada ide kreatif. Usaha menjadi juara meliputi membujuk dan mempengaruhi karyawan dan juga menekan dan bernegosiasi. Untuk mengimplementasikan inovasi sering dibutuhkan koalisi, mendapatkan kekuatan dengan menjual ide kepada rekan yang berpotensi.

Tahap keempat adalah aplikasi. Dalam fase ini meliputi perilaku karyawan yang ditujukan untuk membangun, menguji dan memasarkan pelayanan baru. Hal ini berkaitan dengan membuat inovasi dalam bentuk proses kerja yang baru ataupun dalam proses rutin yang biasa dilakukan.

George \& Zhou, (2001) menyatakan tentang karakter dari individu yang memiliki perilaku inovatif adalah: 1) Mencari tahu teknologi baru, proses, teknik dan ide-ide baru, 2) Menghasilkan ide-ide kreatif, 3) Memajukan dan memperjuangkan ide-ide ke orang lain, 4) Meneliti dan menyediakan sumber daya yang diperlukan untuk mewujudkan ideide baru, 5) Mengembangkan rencana dan jadwal yang matang untuk mewujudkan ide baru tersebut, dan 6) Kreatif. 
Untuk mengoperasionalisasi perilaku inovatif berdasarkan penelitian yang dilakukan Scott \& Bruce, (1994) dan (Janssen, 2004) dalam Jong \& Hartog, (2007) dengan menghubungkan perilaku inovatif dengan fase dalam proses inovasi. Maka Jong mengemukakan bahwa perilaku inovatif berasal dari 13 dimensi yaitu: pemodelan peran Inovatif, stimulasi Intelektual, stimulasi penyebaran pengetahuan, memberi pantangan, konsultasi, mendelegasikan dukungan untuk inovasi, organisasi, umpan balik, pengakuan, penghargaan, penyediaan sumber daya, dan pemantauan tugas.

\subsection{Perilaku Berbagi Pengetahuan}

Pengetahuan merupakan aset penting bagi perusahaan dalam memenangkan persaingan. Sementara sumber daya-sumber daya lainnya mudah untuk ditiru oleh pesaing, tidak demikian dengan sumber daya pengetahuan, yang dituangkan dalam inovasi. Pertimbangan mengenai pentingnya pengetahuan membuat banyak organisasi sadar akan pentingnya manajemen pengetahuan (knowledge management). Manajemen pengetahuan memungkinkan penciptaan, transfer dan penerimaan pengetahuan menjadi lebih efektif.

Banyak definisi mengenai manajemen pengetahuan yang dikemukakan para ahli dan peneliti, antara lain Tiwana, (2000) mendefinisikan manajemen pengetahuan sebagai usaha untuk menciptakan nilai bisnis dan untuk menghasilkan keunggulan kompetitif melalui pengetahuan yang dimiliki organisasi. Probst, (1998) menyatakan bahwa manajemen pengetahuan merupakan kegiatan menciptakan dan mentransfer pengetahuan sehingga pengetahuan tersebut dapat dimanfaatkan oleh organisasi.

Manajemen pengetahuan semakin penting karena saat ini sebuah perusahaan memiliki keunggulan bukan lagi disebabkan oleh mesin dan fasilitas fisik yang dimilikinya tetapi oleh aset pengetahuannya Lumbantobing, (2011), dimana aset pengetahuan tersebut yang menggerakkan sumber daya-sumber daya lain secara keseluruhan.

Berbagi pengetahuan adalah kontribusi individu terhadap pengetahuan kolektif organisasi yang secara bertahap diterima sebagai topik riset yang penting. Dalam organisasi, pengetahuan dalam berbagai bentuk dokumen terkait pekerjaan, peraturanperaturan organisasi, prosedur kerja, pengalaman personal dan cara-cara yang sering dibagi antara pekerja (Hansen et al., 2002; Jabar, Yeong, \& Sidi, 2012; Mcdermott \& O’Dell, 2001).

Menurut Lumbantobing (2011) istilah berbagi pengetahuan (knowledge sharing) dan transfer pengetahuan (knowledge transfer) sering digunakan dengan asumsi memiliki makna yang sama. Menurut Raskov (2007) dalam Lumbantobing, 2011) ada perbedaan dari istilah berbagi pengetahuan dan transfer pengetahuan. Berbagi pengetahuan terjadi antar individu dalam suatu komunitas, dimana individu berinteraksi dan berbagi pengetahuan dalam suatu ruang maya atau tatap muka. Sehingga unit analisis dari 
berbagi pengetahuan adalah individu. Sedangkan transfer pengetahuan terjadi antar kelompok, bahkan organisasi, dimana satu kelompok berinteraksi dengan kelompok lain dalam rangka berbagi pengetahuan. Sehingga unit analisis transfer pengetahuan adalah kelompok atau unit organisasi.

Pentingnya berbagi pengetahuan dalam suatu organisasi diungkapkan dalam berbagai pernyataan. Berbagi pengetahuan penting dengan memindahkan pengetahuan dalam diri individu ke level organisasi, hal ini merubah kepada nilai ekonomis dan kompetitif (Hendriks, 1999). Menurut Stevens, Millage, \& Clark, (2010), pemindahaan pengetahuan adalah proses penting yang memberi organisasi keunggulan kompetitif dengan mengoptimalkan pengetahuan yang mereka miliki.

Menurut Lumbantobing, (2011) berbagi pengetahuan adalah proses yang sistematis dalam mengirimkan, mendistribusikan dan mendiseminasi pengetahuan dan konteks multidimensi dari seorang atau organisasi kepada orang atau organisasi lain yang membutuhkan melalui metoda dan media yang variatif. Dapat disimpulkan definisi dari berbagi pengetahuan adalah aktifitas memindahkan dan menyebarkan pengetahuan dari satu orang, kelompok, atau organisasi kepada yang lainnya. Definisi ini termasuk pengetahuan tacit (pengetahuan yang terdapat dalam pikiran) yang personal, dalam konteks khusus dan oleh karena itu sulit untuk diformalisasi dan komunikasi serta pengetahuan eksplisit yang dapat ditularkan secara resmi dan dengan bahasa yang sistematik Nonaka \& Takeuchi, (1995).

\subsection{Efikasi Diri}

Menurut Bandura, (1997) efikasi diri adalah penilaian seseorang tentang kemampuannya sendiri untuk menjalankan perilaku tertentu atau mencapai tujuan tertentu. Efikasi diri adalah keyakinan seseorang bahwa ia mampu melakukan tugas tertentu dengan baik. Efikasi diri memiliki keefektifan yaitu individu mampu menilai dirinya memiliki kekuatan untuk menghasilkan sesuatu yang diinginkan. Tingginya efikasi diri yang dipersepsikan akan memotivasi individu secara kognitif untuk bertindak secara tepat dan terarah, terutama apabila tujuan yang hendak dicapai merupakan tujuan yang jelas. Pikiran individu terhadap efikasi diri menentukan seberapa besar usaha yang dicurahkan dan seberapa lama individu akan tetap bertahan dalam menghadapi hambatan atau pengalaman yang tidak menyenangkan. Efikasi diri selalu berhubungan dan berdampak pada pemilihan perilaku, motivasi dan keteguhan individu dalam menghadapi setiap persoalan. Cara untuk menganalisis perbedaan motivasi dengan pencapaian mengedepankan efikasi diri individu yaitu kepercayaan bahwa seseorang dapat menguasai suatu situasi dan menghasilkan akhir yang baik.

Menurut Kreitner \& Kinicki, (2004) efikasi diri adalah keyakinan seseorang mengenai peluangnya untuk berhasil mencapai tugas tertentu. Efikasi diri adalah penilaian diri, apakah dapat melakukan tindakan yang baik atau buruk, efikasi ini berbeda dengan aspirasi, karena cita-cita menggambarkan sesuatu yang ideal yang 
seharusnya dapat dicapai, sedangkan efikasi diri menggambarkan penilaian kemampuan diri.

Robbins \& Judge, (2008) menyebutkan bahwa efikasi diri, yang juga dikenal dengan teori kognitif sosial, atau terori penalaran sosial, merujuk pada keyakinan individu bahwa dirinya mampu menjalankan suatu tugas. Semakin tinggi efikasi diri, semakin yakin pada kemampuan untuk menyelesaikan tugas atau mengerjakan sesuatu.

Menurut Pajares, (2002), efikasi diri mempengaruhi pilihan-pilihan dan tindakan individu, menentukan seberapa besar usaha-usaha yang dilakukan individu dan mempengaruhi tingkat stres dan kegelisahan individu. Seseorang yang memiliki efikasi diri yang tinggi akan memiliki kepribadian yang baik karena individu ini memiliki keyakinan mengenai kemampuannya sehingga pada akhirnya akan membentuk perilaku yang positif yang nantinya akan membuat individu tersebut mengalami peningkatan kinerjanya.

Menurut Bandura, (2012), pengukuran efikasi diri yang dimilki seseorang mengacu pada tiga dimensi. Ia menyebutkan bahwa ada tiga dimensi efikasi diri, yaitu magnitude, generality, dan strength. Dimensi magnitude berkaitan dengan derajat kesulitan tugas. Apabila tugas-tugas yang dibebankan pada individu disusun menurut tingkat kesulitannya, maka perbedaan efikasi diri secara individual mungkin terbatas pada tugas-tugas yang sederhana, menengah atau tinggi. Individu akan melakukan tindakan yang dirasakan mampu untuk dilaksanakannya dan akan mengalihkan tugastugas yang diperkirakan di luar batas kemampuan yang dimilikinya. Dimensi generality berhubungan dengan keyakinan seseorang terhadap kemampuan diri dapat berbeda dalam hal generalisasi. Maksudnya seseorang mungkin menilai keyakinan dirinya untuk aktivitas-aktivitas tertentu saja. Dimensi strength berkaitan dengan tingkat kekuatan atau kemantapan seseorang terhadap keyakinannya. Tingkat efikasi diri yang lebih rendah mudah digoyahkan oleh pengalaman-pengalaman yang memperlemahnya. Sedangkan, orang yang memiliki efikasi diri yang kuat akan tekun dalam meningkatkan usahanya meskipun dijumpai pengalaman yang memperlemahnya.

Dimensi-dimensi pada efikasi diri, akan menghasilkan fungsi-fungsi dari efikasi diri yang akan berpengaruh bagi karyawan yaitu: Pemilihan aktivitas, dalam kehidupan sehari-hari individu dituntut untuk membuat keputusan mengenai aktivitas-aktivitas yang akan dijalani dan berapa lama waktu yang di butuhkan untuk menjalaninya. Pengambilan keputusan tersebut dipengaruhi oleh penilaian diri terhadap kemampuan yang dimilikinya (Bandura, 1997). Apabila individu tersebut dihadapkan pada aktivitas atau situasi yang dianggap melampaui kemampuannya, maka akan terjadi kecenderungan untuk menghindari situasi tersebut dan akan memilih aktivitas yang dinilai mampu untuk dilakukan.

Pengaruh efikasi diri yang baik adalah ketika keyakinan yang dimiliki seorang individu dapat mendorongnya untuk memilih aktivitas yang realitis dan menantang, serta 
memotivasi perkembangan kemampuan yang dimilikinya. Fungsi yang kedua adalah besarnya usaha dan daya tahan dalam menghadapi rintangan atau pengalaman yang tidak menyenangkan. Penilaian efikasi diri juga menentukan seberapa besar usaha yang akan dikeluarkan dan berapa lama seseorang akan kuat dalam menghadapi kesulitan atau pengalaman yang tidak menyenangkan. Semakin tinggi efikasi diri yang dimilki individu, maka semakin giat usaha yang dilakukan saat menghadapi situasi yang tidak menyenangkan. Sebaliknya individu dengan efikasi diri rendah akan mengurangi usahanya atau menyerah pada situasi yang tidak menyenangkan. Fungsi yang ketiga adalah pola berpikir dan reaksi emosional. Individu yang memiliki efikasi diri tinggi akan lebih berpacu pada rintangan yang dihadapinya dan menganggap kegagalan yang didapatnya adalah hasil darikurangnya usaha yang dilakukan. Sebaliknya individu dengan efikasi diri rendah cenderung memandang kesulitan lebih berat dari yang sebenarnya. Pola pikir inilah yang menciptakan stres dan menghambat penggunaan kemampuandiri secara optimal sehingga kegagalan yang didapat adalah hasil dari rendahnya kemampuan yang dimiliki. Fungsi yang ke empat adalah sebagai peramal tingkah laku selanjutnya.

Dengan demikian orang-orang yang memiliki efikasi diri tinggi memiliki keterlibatan yang lebih banyak dengan lingkungan sekitarnya. Demikian pula dalam mengerjakan tugas dimasa yang akan datang dia akan menjadi lebih terlibat dan tidak mudah menyerah karena menurut mereka usaha yag dihasilkan disebabkan karena kerja keras dan kemampuan mereka. Sebaliknya bagi orang yang memiliki efikasi diri yang rendah ia akan menghindar dari keterlibatan mengerjakan tugas bahkan cenderung lebih pemalu dan pasrah dalam menerima hasil. Fungsi yang kelima adalah sebagai penentu performasi selanjutnya. Banyak hasil penelitian yang menunjukan bahwa efikasi diri secara signifikan mempengaruhi prestasi kerja yang ditampilkan seseorang. Solomon (1994) dalam Stenberg, (1990) mengatakan bahwa selain dapat meningkatkan kinerja, efikasi diri juga dapat meningkatkan besarnya usaha seseorang dalam menyelesaikan suatu tugas yang dianggapnya mudah, yang pada akhirnya akan meningkatkan prestasi kerja individu tersebut.

\subsection{Hubungan antara Berbagi pengetahuan dengan Perilaku Inovatif}

Berbagi pengetahuan behavior diartikan sebagai derajat dimana individu benarbenar membagi pengatahuan yang dimiliki, diciptakan, dan dibutuhkan kepada orang lain (Bock \& Kim, 2002; Bock, Zmud, Kim, \& Lee, 2005). Perilaku inovatif sendiri didefinisikan sebagai penemuan yang disengaja, promosi, dan realisasi atas ide baru dalam peran kerja, kerja kelompok, atau organisasi, yang berfungsi untuk menguntungkan performa kerja, kelompok, atau organisasi (Janssen, 2004).

Berbagi pengetahuan merupakan salah satu faktor penting untuk menciptakan keunggulan bersaing organisasi, yaitu menghasilkan dan menciptakan inovasi dengan cepat (Abdallah, Khalil, \& Divine, 2012). Selain menciptakan inovasi, berbagi pengetahuan juga digunaan untuk memaksimalkan manfaat aset intagible organisasi. 
Berbagi pengetahuan yang terjadi antara individu yang terlibat dalam sebuah bisnis atau organisasi akan mampu menciptakan kerjasama yang saling memberi dan menerima pengetahuan sehingga dapat mendorong terciptanya inovasi. Berbagi pengetahuan mampu meningkatkan kemampuan untuk melakukan inovasi serta mengoptimalkan kemampuan sumber daya manusia untuk menemukan ide-ide kreatif (Lin, 2007; Rahab et al., 2011). Beberapa penelitian terdahulu (Akhavan, Hosseini, Abbasi, \& Manteghi, 2015; Hassan, Asif, Waqar, Khalid, \& Abbas, 2018; Radaelli, Lettieri, Mura, \& Spiller, 2014) mengemukakan adanya pengaruh positif dan signifikan antara perilaku berbagi pengetahuan dan perilaku inovatif. Hipotesis yang digunakan adalah:

Hipotesis 1: Perilaku berbagi pengetahuan berpengaruh positif dan signifikan terhadap perilaku inovatif.

\section{5. Hubungan antara Efikasi diri dengan Perilaku Inovatif}

Untuk berperilaku inovatif diperlukan keyakinan dari diri seseorang bahwa ia mampu berperilaku demikian. Tanpa adanya keyakinan diri tidak mungkin mewujudkan perilaku tertentu. Lee \& Bobko, (1994) melakukan riset yang menyimpulkan bahwa individu yang memiliki efikasi diri pada situasi tertentu akan mencurahkan semua usaha dan perhatiannya sesuai dengan situasi dalam mencapai tujuannya.

Beberapa riset terdahulu mengenai hubungan efikasi diri dan perilaku inovatif telah dilakukan. (Hsiao et al., 2015; Kumar \& Uzkurt, 2010; Momeni, 2014; Parthasarathy \& Premalatha, 2017) menyatakan adanya pengaruh hubungan yang positif antara self efficacy dan perilaku inovasi. Menurut pendapat mereka, seorang pekerja yang memiliki perilaku inovasi yang tinggi berarti memiliki efikasi diri yang tinggi pula. Apabila efikasi diri seorang pekerja meningkat, dimana ketekunan, kemauan, dan ketahanan terhadap pekerjaan meningkat, maka akan berdampak pada perilaku inovasi mereka (Li, 2013). Hipotesis yang digunakan adalah:

Hipotesis 2: Efikasi diri berpengaruh positif dan signifikan terhadap perilaku inovatif.

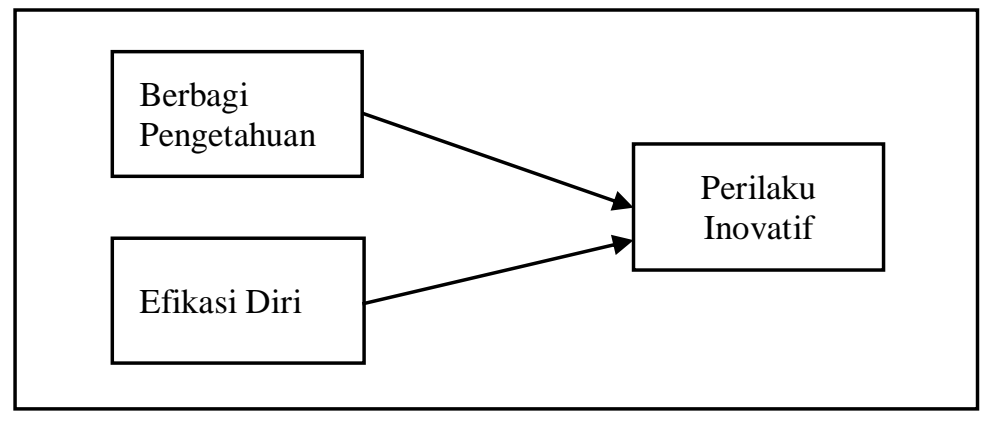

Gambar 1. Model Penelitian

\section{METODA PENELITIAN}

Penelitian ini mengunakan jenis penelitian survei dan penelitian asosiatif berupa penelitian kausal dengan metode regresi linier berganda. Variabel dependen adalah 
perilaku inovatif (Y), dengan indikator: merasa produk yang ada masih bisa dikembangkan, memiliki ide-ide yang bagus dalam pekerjaan, kemampuan komunikasi yang baik dalam menyampaikan ide baru, berusaha agar gagasan diterima oleh atasan atau organisasi, berusaha agar gagasan yang saya miliki dapat diaplikasikan, mencoba motif baru dalam proses menenun, mencoba metode baru dalam menenun (Jong \& Hartog, 2007). Variabel independen adalah berbagi pengetahuan $\left(X_{1}\right)$ dan efikasi diri $\left(\mathrm{X}_{2}\right)$. Dengan masing-masing indikator sebagai berikut: Indikator untuk variabel berbagi pengetahuan adalah: membagi pengetahuan, keterampilan dan informasi tentang kerajinan kain tenun kepada rekan saya walaupun tidak diminta, membagi pengetahuan, keterampilan dan informasi tentang kerajinan kain tenun kepada rekan saya ketika diminta, menerima pengetahuan, keterampilan dan informasi tentang kerajinan kain tenun dari sesama penenun, dan meminta pengetahuan, keterampilan dan informasi tentang kerajinan kain tenun dari sesama penenun Davenport \& Prusak, (2000). Indikator untuk variabel efikasi diri adalah: kemampuan yang saya miliki dapat memberikan tambahan pengetahuan bagi orang lain, keahlian yang saya miliki diperlukan dalam menenun, pengetahuan yang saya berikan pada sesama penenun berbeda dengan yang dimiliki oleh rekan lain, dan penenun lain dapat memberikan pengetahuan lebih berharga dari pada yang saya miliki (Lin, 2007; Rahab et al., 2011).

Objek penelitian adalah perajin tenun di Desa Sumber harapan Kabupaten Sambas, Propinsi Kalimantan Barat. Data dikumpulkan melalui kuesioner yang dibagikan kepada 50 orang perajin tenun. Uji instrumen dilakukan dengan uji validitas dan reliabilitas. Alat analisis menggunakan regresi linier berganda dengan program SPSS 20.0., dengan persamaan regresi:

$\mathrm{Y}=\mathrm{b}_{1} \mathrm{X}_{1}+\mathrm{b}_{2} \mathrm{X}_{2}$

Dimana:

$\mathrm{b}_{1}, \mathrm{~b}_{2}=$ Koefisien konstanta

$\mathrm{X}_{1} \quad=$ Berbagi pengetahuan

$\mathrm{X}_{2} \quad=$ Efikasi diri

$\mathrm{Y}=$ Perilaku inovatif

Untuk meyakinkan bahwa persamaan garis regresi yang diperoleh adalah linier dan valid untuk mencari peramalan, maka sebelum dilakukan analisis regresi terlebih daulu dilakukan uji asumsi klasik, yaitu dengan menggunakan uji normalitas, uji linieritas, uji heterokedastisitas dan uji multikolinearitas. 


\section{HASIL PENELITIAN DAN PEMBAHASAN}

\subsection{Uji Validitas dan Reliabilitas}

Untuk mengetahui kevalidan item pertanyaan yang digunakan dalam pelaksanaan penelitian, maka digunakan uji validitas. Adapun uji validitas dari semua variabel penelitian adalah sebagai berikut:

Tabel 1. Hasil Uji Validitas Pertanyaan Kuisioner Penelitian

\begin{tabular}{ccccc}
\hline \multirow{2}{*}{ Variabel } & Indikator & $\begin{array}{c}\text { Corrected Item-Total } \\
\text { Correlation }\end{array}$ & Standar & Ket \\
\hline \multirow{2}{*}{ Perilaku Inovatif } & Pertanyaan 1 & 0,7457 & 0,3610 & Valid \\
\cline { 2 - 5 } & Pertanyaan 2 & 0,7092 & 0,3610 & Valid \\
\cline { 2 - 5 } & Pertanyaan 3 & 0,6735 & 0,3610 & Valid \\
\cline { 2 - 5 } & Pertanyaan 4 & 0,6923 & 0,3610 & Valid \\
\cline { 2 - 5 } & Pertanyaan 5 & 0,6349 & 0,3610 & Valid \\
\cline { 2 - 5 } pengetahuan & Pertanyaan 6 & 0,6332 & 0,3610 & Valid \\
\cline { 2 - 5 } & Pertanyaan 7 & 0,8204 & 0,3610 & Valid \\
\cline { 2 - 5 } & Pertanyaan 8 & 0,6191 & 0,3610 & Valid \\
\cline { 2 - 5 } & Pertanyaan 9 & 0,8934 & 0,3610 & Valid \\
\cline { 2 - 5 } & Pertanyaan 10 & 0,7258 & 0,3610 & Valid \\
\cline { 2 - 5 } Efikasi diri & Pertanyaan 11 & 0,9112 & 0,3610 & Valid \\
\cline { 2 - 5 } & Pertanyaan 12 & 0,8504 & 0,3610 & Valid \\
\cline { 2 - 5 } & Pertanyaan 13 & 0,6074 & 0,3610 & Valid \\
\cline { 2 - 5 } & Pertanyaan 14 & 0,7735 & 0,3610 & Valid \\
\cline { 2 - 5 } & Pertanyaan 15 & 0,6639 & 0,3610 & Valid \\
\hline
\end{tabular}

Reliabilitas diukur dari koefisien korelasi antara percobaan pertama dan kedua. Bila koefisien Alpha Cronbach's > 0,6 maka instrument tersebut dikatakan reliable (Ghozali, 2013). Dari pengujian yang dilakukan dengan SPSS, diperoleh hasil pengujian reliabilitas berikut ini.

Tabel 2. Hasil Uji Reabilitas Variabel Penelitian

\begin{tabular}{lcc}
\hline \multicolumn{1}{c}{ Pertanyaan Kuisioner } & Alpha Cronbach's & Keterangan \\
\hline Perilaku Inovatif $(\mathrm{Y})$ & 0,816 & Reliabel \\
\hline Berbagi Pengetahuan $\left(\mathrm{X}_{1}\right)$ & 0,773 & Reliabel \\
\hline Efikasi diri $\left(\mathrm{X}_{2}\right)$ & 0,676 & Reliabel \\
\hline
\end{tabular}

Berdasarkan uji reliabilitas di atas dapat diketahui bahwa semua variabel mempunyai koefisien Alpha Cronbach > 0,6 sehingga dapat disimpulkan bahwa semua variabel reliabel.

\subsection{Deskripsi Variabel Penelitian}

\subsubsection{Tanggapan Responden Terhadap Perilaku Berbagi pengetahuan}

Pengukuran variabel berbagi pengetahuan pada penelitian ini meliputi 4 indikator yang tercantum dalam 4 item. Tabel 3 menunjukkan bahwa tanggapan responden 
terhadap indikator berbagi pengetahuan sebesar 201,5 yang berada dalam kategori baik. Item yang di tanggapi dengan nilai rata-rata tertinggi adalah item nomor 3 dengan nilai 223 yakni tentang menerima pengetahuan, keterampilan dan informasi tentang kerajinan kain tenun dari sesama penenun. Sedangkan item dengan nilai terendah adalah item nomor 2 yaitu membagi pengetahuan, keterampilan dan informasi tentang kerajinan kain tenun kepada rekan saya ketika diminta. Artinya perilaku berbagi pengetahuan perajin tenun di Kabupaten Sambas sudah baik. Berikut rekapitulasi tanggapan responden di tabel 3 .

Tabel 3. Tanggapan Responden Terhadap Berbagi pengetahuan

\begin{tabular}{|c|c|c|c|c|c|c|c|c|}
\hline No. & Pertanyaan & $\frac{\mathrm{SS}}{\mathrm{F}}$ & $\frac{\mathrm{S}}{\mathrm{F}}$ & $\begin{array}{l}\mathrm{R} \\
\mathrm{F}\end{array}$ & $\frac{\mathrm{TS}}{\mathrm{F}}$ & $\frac{\text { STS }}{\mathrm{F}}$ & $\begin{array}{c}\text { Jumlah } \\
\text { X }\end{array}$ & $\begin{array}{c}\text { Jumlah } \\
\text { F }\end{array}$ \\
\hline 1. & $\begin{array}{l}\text { Saya membagi pengetahuan, } \\
\text { keterampilan dan informasi } \\
\text { tentang kerajinan kain tenun } \\
\text { kepada rekan saya walaupun } \\
\text { tidak diminta. }\end{array}$ & 19 & 21 & 6 & 4 & 0 & 205 & 50 \\
\hline 2. & $\begin{array}{l}\text { Saya membagi pengetahuan, } \\
\text { keterampilan dan informasi } \\
\text { tentang kerajinan kain tenun } \\
\text { kepada rekan saya ketika diminta. }\end{array}$ & 7 & 15 & 19 & 9 & 0 & 170 & 50 \\
\hline 3. & $\begin{array}{l}\text { Saya menerima pengetahuan, } \\
\text { keterampilan dan informasi } \\
\text { tentang kerajinan kain tenun dari } \\
\text { sesama penenun. }\end{array}$ & 23 & 27 & 0 & 0 & 0 & 223 & 50 \\
\hline 4. & $\begin{array}{l}\text { Saya meminta pengetahuan, } \\
\text { keterampilan dan informasi } \\
\text { tentang kerajinan kain tenun dari } \\
\text { sesama penenun. }\end{array}$ & 18 & 23 & 8 & 1 & 0 & 208 & 50 \\
\hline & Rata-rat & & & & & & 201,5 & \\
\hline
\end{tabular}

\subsubsection{Tanggapan Responden Terhadap Efikasi Diri}

Pengukuran efikasi diri pada penelitian ini meliputi 4 indikator yang tercantum dalam 4 item. Berikut rekapitulasi tanggapan responden di tabel 4.

Tabel 4. Tanggapan Responden Terhadap Efikasi Diri

\begin{tabular}{|c|c|c|c|c|c|c|c|c|}
\hline No. & Pertanyaan & $\frac{S S}{F}$ & $\mathrm{~S}$ & $\frac{\mathrm{R}}{\mathrm{F}}$ & $\frac{\mathrm{TS}}{\mathrm{F}}$ & $\frac{\text { STS }}{F}$ & $\begin{array}{c}\text { Jumlah } \\
X\end{array}$ & Jumlah F \\
\hline 1. & $\begin{array}{l}\text { Kemampuan yang saya miliki dapat } \\
\text { memberikan tambahan pengetahuan } \\
\text { bagi sesama penenun. }\end{array}$ & 15 & 35 & 0 & 0 & 0 & 215 & 50 \\
\hline 2. & $\begin{array}{l}\text { Keahlian yang saya miliki } \\
\text { diperlukan dalam menenun. }\end{array}$ & 23 & 27 & 0 & 0 & 0 & 223 & 50 \\
\hline 3. & $\begin{array}{l}\text { Pengetahuan yang saya berikan } \\
\text { berbeda dengan yang dimiliki rekan- } \\
\text { rekan saya }\end{array}$ & 13 & 33 & 2 & 2 & 0 & 207 & 50 \\
\hline 4. & $\begin{array}{l}\text { Penenun lain dapat memberikan } \\
\text { pengetahuan lebih } \\
\text { daripada yang saya miliki. }\end{array}$ & 17 & 29 & 3 & 1 & 0 & 212 & 50 \\
\hline & Rata-rata & & & & & & 214,25 & 50 \\
\hline
\end{tabular}


Tabel 4 menunjukkan bahwa rata-rata tanggapan responden terhadap indikator efikasi diri sebesar 214,25 yang berada dalam kategori sangat tinggi. Item yang di tanggapi dengan nilai tertinggi adalah item nomor 2 dengan nilai 223 yakni tentang Keahlian yang saya miliki diperlukan dalam menenun. Sedangkan item dengan nilai terendah adalah item nomor 3 yaitu tentang Pengetahuan yang saya berikan berbeda dengan yang dimiliki rekan-rekan saya. Dapat disimpulkan bahwa perajin tenun di Kabupaten Sambas memiliki efikasi diri yang sangat tinggi.

\subsubsection{Tanggapan Responden Terhadap Perilaku Inovatif}

Pengukuran perilaku inovatif pada penelitian ini meliputi 7 indikator yang tercantum dalam 7 item. Berikut ini di kemukakan rekapitulasi tanggapan responden terhadap variabel perilaku inovatif beserta indikatornya.

Tabel 5. Tanggapan Responden Terhadap Perilaku Inovatif

\begin{tabular}{|c|c|c|c|c|c|c|c|c|}
\hline \multirow{2}{*}{ No. } & \multirow{2}{*}{ Pertanyaan } & SS & $\mathrm{S}$ & $\mathrm{R}$ & TS & STS & \multirow{2}{*}{$\begin{array}{l}\text { Jumlah } \\
\text { X }\end{array}$} & \multirow{2}{*}{$\begin{array}{c}\text { Jumlah } \\
\text { F }\end{array}$} \\
\hline & & $\mathrm{F}$ & $\mathrm{F}$ & $\mathrm{F}$ & $\mathrm{F}$ & $\mathrm{F}$ & & \\
\hline 1. & $\begin{array}{l}\text { Saya merasa produk kain tenun } \\
\text { yang ada masih bisa dikembangkan. }\end{array}$ & 43 & 7 & 0 & 0 & 0 & 243 & 50 \\
\hline 2. & $\begin{array}{l}\text { Saya memiliki ide-ide baru dalam } \\
\text { hal menenun. }\end{array}$ & 21 & 29 & 0 & 0 & 0 & 221 & 50 \\
\hline \multirow[t]{2}{*}{3.} & Saya memiliki kemampuan & & & & & & & \\
\hline & $\begin{array}{l}\text { komunikasi yang baik dalam } \\
\text { menyampaikan ide-ide } \\
\text { dipikirkan }\end{array}$ & 13 & 33 & 4 & 0 & 0 & 209 & 50 \\
\hline 4. & $\begin{array}{l}\text { Saya berusaha agar gagasan yang } \\
\text { saya miliki diterima oleh pihak yang } \\
\text { terkait dengan kerajinan kain tenun. }\end{array}$ & 8 & 36 & 6 & 0 & 0 & 202 & 50 \\
\hline 5. & $\begin{array}{l}\text { Saya berusaha agar gagasan yang } \\
\text { saya miliki dapat diaplikasikan }\end{array}$ & 28 & 22 & 0 & 0 & 0 & 228 & 50 \\
\hline 6. & $\begin{array}{l}\text { Saya sering mencoba motif baru } \\
\text { dalam proses menenun. }\end{array}$ & 20 & 30 & 0 & 0 & 0 & 220 & 50 \\
\hline 7. & $\begin{array}{l}\text { Saya sering mencoba cara baru } \\
\text { dalam mengasilkan kain tenun. }\end{array}$ & 15 & 26 & 9 & 0 & 0 & 206 & 50 \\
\hline & Rata-rata & & & & & & 218,43 & 50 \\
\hline
\end{tabular}

Tabel 5 menunjukkan bahwa tanggapan responden terhadap indikator perilaku inovatif sebesar 218,43 yang berada dalam kategori sangat baik. Item yang ditanggapi paling tinggi oleh responden adalah Saya merasa produk kain tenun yang ada masih bisa dikembangkan, sedangkan item yang ditanggapi paling rendah oleh responden adalah Saya berusaha agar gagasan yang saya miliki diterima oleh pihak yang terkait dengan kerajinan kain tenun. Artinya perilaku inovatif perajin tenun di Kabupaten Sambas sudah sangat baik.

\subsection{Uji Asumsi Klasik}

Uji asumsi klasik terdiri dari uji normalitas, uji linieritas, uji multikolinieritas, dan uji heteroskedastisitas. Uji normalitas residual dilakukan dengan menggunakan uji one- 
sample Kolmogrov-Smirnov. Korelasi antara Berbagi pengetahuan (X1), Efikasi diri ( $\left.\mathrm{X}_{2}\right)$, dan Perilaku inovatif (Y) dengan Unstandardized Residual menghasilkan nilai signifikansi secara keseluruhan sebesar 0,200. Karena nilai signifikansi korelasi lebih besar dari 0,05 dapat disimpulkan bahwa variabel yang digunakan dalam penelitian ini telah berdistribusi normal.

Linearitas akan terpenuhi dengan asumsi jika signifikansinya pada Deviation from linearity-nya lebih besar dari 0,05. Dari uji linieritas yang dilakukan, signifikansi deviation from linearity kedua persamaan melewati standar signifikansi 0,05 yang ditetapkan pada teori di atas. Hal tersebut berarti terjadi hubungan yang linear antara variabel bebas $\mathrm{X}_{1}$ (berbagi pengetahuan), $\mathrm{X}_{2}$ (efikasi diri) dengan variabel terikat $\mathrm{Y}$ (perilaku inovatif).

Dari analisis multikolinearitas diperoleh nilai Variance Inflation Factor (VIF) pada semua variabel independen berada tidak jauh dari nilai 1 atau lebih kecil dari 10 maka dapat diambil kesimpulan bahwa tidak terdapat gejala multikolinearitas, sehingga regresi sah untuk digunakan. Dalam penelitian ini uji heterokesdastisitas dilakukan dengan melihat pola gambar scatterplots. Hasil pengujian heterokedastisitas menunjukkan tidak terbentuk pola tertentu pada gambar scatterplots, sehingga dapat disimpulkan tidak terdapat gejala heteroskedastisitas.

\subsection{Analisis Regresi}

Teknik analisis yang digunakan untuk pengujian persamaan regresi dan hipotesis dalam penelitian ini adalah Analisis Regresi Linear Berganda yang dihitung dengan Program SPSS 20.0 for Windows. Pada Tabel 6, output analisis regresi tabel Coefficients, terdapat sub bagian yang menunjukkan besarnya beta (kolom Unstandardized Coefficients b) untuk masing-masing variabel independen yang akan digunakan untuk membuat persamaan garis regresi yang dihasilkan analisis tersebut.

Tabel 6. Output Uji Regresi Berganda

\begin{tabular}{llcc}
\hline \multicolumn{1}{c}{ Variabel } & Koefisien & $\mathrm{t}$ & \multicolumn{1}{c}{ Sig. } \\
\hline (Constant) & & 2.976 & 0,005 \\
\cline { 2 - 4 } Berbagi_Pengetahuan & 0,191 & 1.295 & 0,202 \\
\cline { 2 - 4 } Efikasi_Diri & 0,479 & 3.240 & 0,002 \\
\hline
\end{tabular}

Persamaan garis regresi berganda dapat dinyatakan sebagai berikut :

$$
\begin{aligned}
& Y=b_{1} X_{1}+b_{2} X_{2} \\
& Y=0,191 X_{1}+0,479 X_{2}
\end{aligned}
$$

Persamaan regresi yang terbentuk dapat diartikan sebagai berikut :

1. Nilai koefisien regresi $X_{1}$ (berbagi pengetahuan) sebesar 0,191 menunjukan semakin tinggi perilaku berbagi pengetahuan $\left(\mathrm{X}_{1}\right)$ akan menyebabkan semakin baiknya perilaku inovatif perajin tenun $(\mathrm{Y})$ 
2. Nilai koefisien regresi $X_{2}$ (efikasi diri) sebesar 0,479 menunjukan semakin tinggi efikasi diri $\left(\mathrm{X}_{2}\right)$ akan menyebabkan semakin baiknya perilaku inovatif perajin tenun (Y).

3. Variabel efikasi diri berpengaruh lebih besar terhadap perilaku inovatif dibandingkan dengan perilaku berbagi pengetahuan.

\subsubsection{Koefisien Determinasi $\left(\mathbf{R}^{2}\right)$}

Analisis determinasi merupakan analisis untuk mengetahui persentase sumbangan pengaruh variabel independen secara bersama-sama terhadap variabel dependen. Hasil analisis determinasi dapat dilihat pada Output Model Summary dari hasil analisis regresi linear berganda dengan menggunakan SPSS 20.0.

Tabel 7. Output Uji Regresi Berganda

\begin{tabular}{rrrr}
\hline $\mathrm{R}$ & R Square & $\begin{array}{c}\text { Adjusted } R \\
\text { Square }\end{array}$ & $\begin{array}{c}\text { Std. Error of the } \\
\text { Estimate }\end{array}$ \\
\hline 0,618 & 0,382 & 0,355 & 0,34101 \\
\hline
\end{tabular}

Tabel 7 digunakan untuk mengetahui berapa besar pengaruh secara simultan (bersama-sama) antara variabel independen/bebas berbagi pengetahuan (X1), efikasi diri $\left(\mathrm{X}_{2}\right)$ terhadap variabel dependen/terikat perilaku inovatif $(\mathrm{Y})$. Berdasarkan hasil analisis nilai koefisien determinasi berganda Adjusted $\mathrm{R}$ Square adalah sebesar 0,355 atau $35,5 \%$. Hal ini menunjukkan bahwa persentase pengaruh variabel independen, yaitu berbagi pengetahuan dan efikasi diri terhadap variabel dependen perilaku inovatif sebesar 35,5\%. Atau variasi variabel independen yang digunakan dalam model mampu menjelaskan sebesar 35,5\% variasi dependen, sedangkan sisanya yaitu $64,5 \%$ dipengaruhi oleh variabel lain yang tidak dimasukkan dalam model penelitian ini.

\subsubsection{Pengaruh Berbagi Pengetahuan terhadap Perilaku Inovatif}

Berdasarkan persamaan regresi dan tabel output uji t (tabel 8), pengaruh variabel komitmen organisasional terhadap kinerja karyawan dapat dilihat pada tabel berikut :

Tabel 8. Pengaruh Berbagi Pengetahuan terhadap Perilaku Inovatif

\begin{tabular}{|c|c|c|}
\hline $\mathrm{t}_{\text {hit }}$ & $\mathrm{t}_{\mathrm{tab}}$ & Sig. \\
\hline 1,295 & 1,984 & 0,202 \\
\hline
\end{tabular}

Berdasarkan tabel 8 dapat diambil kesimpulan Nilai $\mathrm{t}$ hitung lebih kecil dari $\mathrm{t}$ tabel untuk $\alpha=0,05$ dan nilai signifikansi 0,202 $>0,05$, sehingga dapat diambil keputusan menerima $\mathrm{H}_{0}$ dan menolak $\mathrm{H}_{1}$, hal ini berarti berdasarkan penelitian tidak terdapat pengaruh yang signifikan dari variabel berbagi pengetahuan $\left(\mathrm{X}_{1}\right)$ terhadap perilaku inovatif $(\mathrm{Y})$. 


\subsubsection{Pengaruh Efikasi Diri terhadap Perilaku Inovatif}

Berdasarkan persamaan regresi dan tabel output uji t (tabel 9), pengaruh variabel efikasi diri terhadap perilaku inovatif dapat dilihat pada tabel berikut :

\section{Tabel 9. Pengaruh Efikasi Diri terhadap Perilaku Inovatif}

\begin{tabular}{|c|c|c|}
\hline $\mathrm{t}_{\text {hit }}$ & $\mathrm{t}_{\mathrm{tab}}$ & Sig. \\
\hline 3,240 & 1,984 & 0,002 \\
\hline
\end{tabular}

Berdasarkan tabel 9 dapat diambil kesimpulan Nilai $\mathrm{t}$ hitung lebih besar dari $\mathrm{t}$ tabel untuk $\alpha=0,05$ dan nilai signifikansi $0,002<0,05$, sehingga dapat diambil keputusan menolak $\mathrm{H}_{0}$ dan menerima $\mathrm{H}_{1}$, hal ini berarti berdasarkan penelitian terdapat pengaruh yang signifikan dari variabel efikasi diri $\left(\mathrm{X}_{2}\right)$ terhadap perilaku inovatif $(\mathrm{Y})$.

Pembuktian hipotesis menggunakan uji $t$, setiap variabel independen yang meliputi perilaku berbagi pengetahuan dan efikasi diri apakah memiliki pengaruh secara parsial tehadap perilaku inovatif perajin tenun di Kabupaten Sambas. Berdasarkan hasil uji t, diketahui variabel perilaku berbagi pengetahuan tidak berpengaruh secara signifikan terhadap perilaku inovatif, sedangkan efikasi diri berpengaruh signifikan terhadap perilaku inovatif.

Hasil uji t menunjukkan bahwa variabel perilaku berbagi pengetahuan tidak berpengaruh signifikan secara parsial terhadap perilaku inovatif, dimana nilai $t$ hitung $<\mathrm{t}$ tabel $(1,295>1,984)$. Hasil penelitian perilaku berbagi pengetahuan tidak berpengaruh signifikan terhadap perilaku inovatif. Hasil penelitian ini tidak mendukung penelitian sebelumnya (Akhavan et al., 2015; Hassan et al., 2018; Radaelli et al., 2014).

Berbagi pengetahuan merupakan salah satu faktor penting untuk menciptakan keunggulan bersaing organisasi, yaitu menghasilkan dan menciptakan inovasi dengan cepat (Abdallah et al., 2012). Selain menciptakan inovasi, berbagi pengetahuan juga digunaan untuk memaksimalkan manfaat aset intagible organisasi.

Berbagi pengetahuan yang terjadi antara individu yang terlibat dalam sebuah bisnis atau organisasi akan mampu menciptakan kerjasama yang saling memberi dan menerima pengetahuan sehingga dapat mendorong terciptanya inovasi. Berbagi pengetahuan mampu meningkatkan kemampuan untuk melakukan inovasi serta mengoptimalkan kemampuan sumber daya manusia untuk menemukan ide-ide kreatif (Lin, 2007; Rahab et al., 2011).

Hasil uji t menunjukkan bahwa variabel efikasi diri memiliki pengaruh secara parsial terhadap perilaku inovatif, dimana nilai t hitung $>t$ tabel $(3,240>1,984)$. Hasil penelitian efikasi diri berpengaruh positif dan signifikan terhadap perilaku inovatif. Hal ini mendukung penelitian beberapa riset terdahulu mengenai hubungan efikasi diri dan perilaku inovatif. Riset (Hsiao et al., 2015; Kumar \& Uzkurt, 2010; Momeni, 2014; Parthasarathy \& Premalatha, 2017) menyatakan adanya pengaruh hubungan yang positif antara efikasi diri dan perilaku inovasi. Menurut pendapat mereka, seorang pekerja 
yang memiliki perilaku inovasi yang tinggi berarti memiliki efikasi diri yang tinggi pula. Apabila efikasi diri seorang pekerja meningkat, dimana ketekunan, kemauan, dan ketahanan terhadap pekerjaan meningkat, maka akan berdampak pada perilaku inovasi mereka (Li, 2013).

\section{SIMPULAN}

Dari hasil analisis yang telah dilakukan, maka dapat diambil kesimpulan sebagai berikut: Perilaku berbagi pengetahuan perajin tenun di Kabupaten Sambas berada pada kategori baik, yang artinya perajin tenun bersedia membagi dan menerima informasi dengan suka rela tentang kerajinan tenun. Efikasi diri perajin tenun di Kabupaten Sambas berada pada kategori sangat tinggi, yang artinya para perajin tenun yakin bahwa mereka dapat menjalankan pekerjaannya sebagai penenun dengan sangat baik. Perilaku inovatif perajin tenun di Kabupaten Sambas berada pada kategori sangat baik, yang artinya para perajin tenun berusaha untuk selalu memperbaharui metode maupun variasi dari kain tenun yang mereka hasilkan. Variabel perilaku berbagi pengetahuan berpengaruh positif namun tidak signifikan terhadap perilaku inovatif perajin tenun di Kabupaten Sambas. Variabel efikasi diri berpengaruh positif dan signifikan terhadap perilaku inovatif perajin tenun di Kabupaten Sambas. Variabel efikasi diri berpengaruh lebih besar terhadap perilaku inovatif dibandingkan perilaku berbagi pengetahuan.

\section{DAFTAR PUSTAKA}

Abdallah, S., Khalil, A., \& Divine, A. (2012). The Impact of Knowledge Sharing on Innovation Capability in United Arab Emirates Organizations. International Journal of Social, Behavioral, Educational, Economic, Business and Industrial Engineering, 6(12), 3588-3591.

Akhavan, P., Hosseini, S. M., Abbasi, M., \& Manteghi, M. (2015). Knowledge-sharing determinants, behaviors, and innovative work behaviors An integrated theoretical view and. Aslib Journal of Information Management, 67(5). https://doi.org/10.1108/AJIM-02-2015-0018

Bandura, A. (1997). Self Efficacy: The Exercise of Control. New York: W. H. Freeman and Company.

Bandura, A. (2012). On the Functional Properties of Perceived Self-Efficacy Revisited. Journal of Management, 38, 9-44. https://doi.org/10.1177/0149206311410606

Bock, G.-W., \& Kim, Y.-G. (2002). Breaking the Myths of Rewards : An Exploratory Study of Attitudes About Knowledge Sharing. Information Resource Management Journal, 15, 14-21.

Bock, G.-W., Zmud, R. W., Kim, Y.-G., \& Lee, J.-N. (2005). Behavioral intention formation in knowledge sharing: Examining the roles of extrinsic motivators, social-psychological forces and organizational climate. MIS Quarterly, 29(1), 87111.

Davenport, T. H., \& Prusak, L. (2000). Working Knowledge: How Organizations 
Manage What They Know. Boston: Harvard Business Press.

George, J. M., \& Zhou, J. (2001). When Openness to Experience and Conscientiousness Are Related to Creative Behavior: An Interactional Approach. Journal of Applied Psychology, 86(3), 513-524. https://doi.org/10.1037//0021-9010.86.3.513

Hansen, M. T., Science, O., Jun, O. M., Hansen, M. T., Hall, M., \& Park, S. F. (2002). Knowledge Networks: Explaining Effective Knowledge Sharing in Multiunit Companies, 13(3), 232-248.

Hassan, H. A., Asif, J., Waqar, N., Khalid, S., \& Abbas, S. K. (2018). The Impact of Knowledge Sharing On Innovative Work Behavior The Impact of Knowledge Sharing On Innovative Work Behavior. Asian Journal of Multidisciplinary Studies, 6(5), 22-25.

Hendriks, P. (1999). Why Share Knowledge? The Influence of ICT on the Motivation for Knowledge Sharing. Knowledge and Process Management, 6(2), 91-100.

Hsiao, H., Tu, Y.-L., Chang, J.-C., \& Chen, S.-C. (2015). The Influence of Teachers' Self-efficacy on Innovative Work Behavior. In International Conference on Social Science and Humanity (pp. 2-7).

Jabar, M. A., Yeong, C. C., \& Sidi, F. (2012). Information Systems Development Knowledge Sharing-Organizational Justice, Physical Distance and Social Interdependence Marzanah A . Jabar, Cheah Chee Yeong and Fatimah Sidi Department of Information System , Faculty of Computer Science and Information T. Journal of Computer Science, 8(1), 31-40.

Janssen, O. (2004). How fairness perceptions make innovative behavior more or less stressful. Journal of Organizational Behavior, 215, 201-215.

Jong, J. P. J. d, \& Hartog, D. N. D. (2007). How Leaders Influence Employees' Innovative Behaviour. European Journal of Innovation Management, 10(1), 41-64. https://doi.org/10.1108/14601060710720546

Kleysen, R. F., \& Street, C. T. (2001). Toward a multi-dimensional measure of individual innovative behavior. Journal of Intellectual Capital, 2(3), 284-296.

Kreitner, R., \& Kinicki, A. (2004). Organizational Behavior. Boston: MA: McGraw-Hill Irwin.

Kumar, R., \& Uzkurt, C. (2010). Investigating the effects of self efficacy on innovativeness and the moderating impact of cultural dimensions. Journal of International Business and Cultural Studies, 1-15.

Lee, C., \& Bobko, P. (1994). Self-Efficacy Beliefs: Comparison of Five Measures. Journal of Applied Psychology, 79(3), 364-369.

Li, C. (2013). Does Self-Efficacy Contribute to Knowledge Sharing and Innovation Effectiveness? A Multi-Level Perspective. In PACIS 2013 Proceedings 3.

Lin, H. (2007). Knowledge sharing and firm innovation capability: an empirical study. International Journal of Manpower, 28(3), 315-332. https://doi.org/10.1108/01437720710755272

Lumbantobing, P. (2011). Manajemen Knowledge Sharing berbasis Komunitas. 
Bandung: Knowledge Management Society Indonesia.

Mcdermott, R., \& O’Dell, C. (2001). Overcoming cultural barriers to sharing knowledge. Journal of Knowledge Management, 5(1), 76-85.

Momeni, M. (2014). The Effect of Employees' Self-Efficacy on Innovative Work Behavior at Social Security Organization Employees in Ardabil Province. Kuwait Chapter of Arabian Journal of Business and Management Review, 3(8), $29-32$.

Nonaka, I., \& Takeuchi, H. (1995). The Knowledge-Creating Company. New York: Oxford University Press.

Pajares. (2002). Overview of Social Cognitive Theory and Self-Efficacy. Retrieved July 12, 2018, from http:www.emory.edu/EDUCATION/mfp/eff.html

Parthasarathy, J., \& Premalatha, T. (2017). Impact of Collective-Efficacy and SelfEfficacy on the Innovative Work Behaviour of Teachers in the Nilgiris District, Tamil Nadu. The International Journal of Indian Psychology, 5(1). https://doi.org/10.25215/0501.019

Probst, G. J. B. (1998). Practical Knowledge Management: A Model That Works.

Radaelli, G., Lettieri, E., Mura, M., \& Spiller, N. (2014). Knowledge Sharing and Innovative Work Behaviour in Healthcare : A Micro-Level Investigation of Direct and Indirect Effects. Creativity and Innovation Management, 23(4), 400-414.

Rahab, Sulistyandari, \& Sudjono. (2011). The Development of Innovation Capability of Small Medium Enterprises Through Knowledge Sharing Process: An Empirical Study of Indonesian Creative Industry. International Journal of Business and Social Science, 2(21), 112-123.

Robbins, S. P., \& Judge. (2008). Perilaku Organisasi. Jakarta: Salemba Empat.

Scott, S. G., \& Bruce, R. A. (1994). Determinants of Innovative Behavior : A Path Model of Individual Innovation in the Workplace. The Academy of Management Journal, 37(3), 580-607.

Stenberg, R. J. (1990). Wisdom and Its Relation to Intelligence and Creativity. In R. J. Stenberg (Ed.), Wisdom: Its Nature, Origins, and Developmen (pp. 142-159). New York: Cambridge University Press.

Stevens, R. H., Millage, J., \& Clark, S. (2010). Waves of Knowledge Management: The Flow between Explicit and Tacit Knowledge. American Journal of Economics and Business Administration, 2(1), 129-135.

Tiwana, A. (2000). Knowledge Management Toolkit, Practical Techniques for Building a Knowledge Management System. New Jersey: Prentice Hall PTR. 